\title{
The Iconography of Mark Antony
}

\author{
RACHAEL KELLY, University of Ulster
}

\section{ABSTRACT}

The story of the lives and deaths of Cleopatra VII of Egypt and her lover, the Roman triumvir Marcus Antonius, have been the subject of considerable mythologisation in the two millennia since their suicides at Alexandria. In recent years, some scholars have noted that the image of Cleopatra has been used, in various texts, to perform cultural anxieties about the meaning of acceptable womanhood. However, whilst there is some evidence (albeit problematic) that the screen Cleopatras of the past forty years have been subject to a recuperation of sorts, there has been no similar recuperation or critical analysis of the image of Antonius (or Antony). This paper seeks to outline the key recurring features of the diverse screen representations of Antony, and to analyse their function in exploring cultural anxieties about acceptable masculinity.

\section{KEYWORDS}

Mark Antony; gender; historical films; masculinity.

On September 2nd $31 \mathrm{BCE}$, just off the promontory of Actium on the west coast of Greece, a sea battle was fought between the forces of the future Emperor Augustus (then known as Caesar Octavianus, or Octavian to modern scholars), and the joint forces of Marcus Antonius and Cleopatra VII of Egypt. It was, essentially, a battle for the hearts and minds of the Roman Empire: Antonius had emerged as the natural political successor to Caesar in the days following Caesar's assassination, 13 years earlier, while Octavian had been posthumously adopted by Caesar as his son and had used this as leverage in his bid to challenge Antony's power. The relationship between the two men was problematic at best, finally emerging in the mid-30s BCE from an uneasy period of joint rule to explicit hostility. Antonius (or Antony, as he is more commonly known to modern audiences), initially in the stronger position, had, in $41 \mathrm{BCE}$, formed an alliance with the most powerful client monarch in the east, Egypt's Macedonian queen, Cleopatra. Whatever semiological status has since been imposed upon their relationship, it seems clear from a study of both parties that its primary function was political, and it was - until the very last moment - a mutually beneficial arrangement. Their defeat at Actium - a combination of bad luck and a series of unlikely successes on the part of Agrippa, Octavian's chief admiral - is the date that many modern historians ascribe to the end of the Roman Republic.

Antony and Cleopatra's defeat at Actium was not only a military loss, but also meant the loss of the propaganda war that had raged between Antony in Alexandria and Octavian in Rome. It is this propaganda war - of which, for obvious reasons, it seems only Octavian's 
version survives - that is the origin of the predictable but complicated mythology that informs the Antony-myth in the popular culture of the last two millennia. In this paper, it is my intention to consider some of the ways in which this mythology has been translated onto the large and small screens over the seventy years covered by the films examined, and to explore the deeper gender anxieties that these representations exhibit - with regards to both the position of the male in the presence of the powerful female, and the self-destructive nature of the feminized man. Masculinity itself has, of course, begun to be subjected to academic interrogation in the past twenty years, with a variety of authors seeking to explore the function of screen texts in setting the terms of acceptable (or desirable, which is, of course, not always the same thing) masculinity. Gibson (2004) examines the shift in masculine iconography of the 1980s, in which the hyper-masculine, muscled torso predominated, to the more androgynous male fashion ideal of the 1990s; Shamir and Travis (2002) seek to interrogate the function of emotional (in)expressivity in constructing masculinity; others (Cohen, 1997; Lehman, 2001, to name only two) have subjected screen masculinity to a more general interrogation in terms of its interplay with hegemonic ideas of maleness. It is within this wider context of critical debate on discursive constructions of the male that I want to address the positioning of Antony as an icon of deficient masculinity. The screen texts under analysis are as follows: Cleopatra (1917), Cleopatra (1934), Caesar and Cleopatra (1946), Serpent of the Nile (1953), Cleopatra (1963), Cleopatra (1999), Imperium: Augustus (2002), Julius Caesar (2002), Rome Season 1 (2005), and Rome Season 2 (2007).

To begin with, it is important to understand that the Antony-icon is itself essentially a construction of gender anxiety, along culturally specific lines which scholars have only recently begun to explore. Most of the information that we have about the historical figure Marcus Antonius (who should be considered as a separate entity to the constructed figure Antony) is derived from sources either explicitly hostile towards him - notably Cicero, whose analyses of Antonius' character have tended to be unproblematically accepted as fact - or else was written after he had passed from living memory and is based on sources that, through a combination of Augustus' probable manipulation of proAntonian documentation following Antony's death (Goltz-Huzar, 1978, p234) and his own popularity during the course of his long reign, are pro-Augustan in nature. Thus Plutarch, writing in the early second century AD, is able to select Antony as an exemplar of flawed manhood - what Shakespeare's Caesar calls 'Th' abstract of all faults, that all men follow.' (Antony and Cleopatra: I.4) Yet, as Catharine Edwards argues, the mechanisms by which Cicero accuses Antony of a staggering level of corruption including the catalogue of vices by which we know him today - are very much in keeping with Roman oratorical convention. 'Such claims functioned as vivid and highly entertaining assertions about the general character of their victims,' she says:

They also served to display the orator's master of the traditional vocabulary of invective. Rhetorical tradition emphasises the importance of inventio, 'elaboration', in all branches of the orator's art.

(Edwards, 1993, p10)

Edwards goes on to note that the exhibition of behaviours associated with the Roman concepts of incontinentia, which loosely translates as a lack of self-control, and mollitia, or effeminacy (although it should be noted that neither word has a direct English equivalent), was considered in Roman discourse to indicate an inability to hold political 
office. In other words, a man who could not govern his own desires was not fit to govern others. Incontinentia could refer to sexual or alcoholic excess, or excessive luxury, mollitia to emotional expressivity or sexual passivity (Roman discourse categorises sexuality as active - gendered male - and passive - gendered female - rather than in terms of heterosexuality and homosexuality so it is not accurate to translate sexual passivity as homosexuality, although it does refer to a sexual act between two men). All of these charges were levelled against Antony, and most have usually been unproblematically reproduced in his screen iconography. Moreover, the gendered division of public and private in ancient Rome made possible the conflation of fitness to rule with masculinity. If the public sphere was traditionally an exclusively male construction, a challenge to one's masculinity was, by definition, once again a challenge to one's ability to govern. It is therefore of great significance that much of the language of Antony's iconography is inherently feminized.

This paper is predicated on the assumption that Antony occupies a problematic semiological position in the significant corpus of artistic texts that have addressed his story over the two millennia since his death. Their narrative imperatives are complicated by their authors' teleological reading of events and this, it would appear, has led to the common denominator of all the artistic re-negotiations of the Antony/Cleopatra story: the inevitability of their defeat. On the one hand, this is relatively easy to account for: the authors of these texts are equipped at the outset with the incontrovertible fact of Augustus's triumph and his successful subsequent tenure as Emperor; it remains only to explain his rivals' defeat and suicides. Given that Augustus's victory historically created a period of peace and prosperity in Rome in direct contrast to the violence and instability of the end of the Republic, and given that the historical sources almost universally paint a negative picture of the historical Antonius, it is not difficult to explain this narrative consensus that apportions the responsibility for their defeat squarely with Antony and Cleopatra themselves. However, it is the means by which this consensus is textually rendered that is problematic. The basic narrative may be teleologically determined, but the series of events through which the conclusion is reached are widely divergent. In the screen texts under analysis, all include quasi-historical events that ideologically position the narrative in line with the Augustan version, but which deviate from the historical record to a greater or lesser degree. It is therefore not sufficient to allow teleological determinacy account for the narrative structure of these texts, as they do not simply reflect the author/reader's foreknowledge of events, but rather ideologically position the reader through structure and characterisation. In this paper, I want to look at some of the ways in which this ideological positioning has been imposed upon Antony.

Before addressing the iconographic conventions of the Antony-icon, it is important to note that his characterisation is entirely dependent on Cleopatra's, and vice versa. Both Lucy Hughes-Hallett (1990) and Francesca T Royster (2003) have noted that the meaning attached to the Cleopatra-icon through the centuries has shifted to reflect contemporaneous attitudes to women (and, specifically, appropriate femininity). This impacts on the meaning attached to Antony, performing Man to her performance of Woman. Initially (1917 - 1953), Cleopatra is constructed as the archetypal femme fatale: she is the focus of the gender-reversal discourse and thus assumes culpability for both Antony's downfall and her own. Antony, therefore - though there may be a token disapproval of the profligate elements of his character that have allowed him to be dominated by the masculinized woman - is essentially absolved of responsibility for his ruin. However, as Cleopatra begins to be recuperated (albeit problematically) as a quasi- 
feminist icon of female empowerment from the middle of the twentieth century, so Antony's screen incarnations experience a compensatory redistribution of the burden of gender anxiety. It is simplistic to argue that Cleopatra's authority is no longer conceived of as essentially damaging from 1963 onwards - indeed, the hegemonic party line is evident in all her constructions. However, it is from this point that the text begins to engage with the possibility of positioning her positively within the narrative. If Cleopatra's usurpation of the (male) position of power is not explicitly negative, then, the narrative cannot hold her explicitly responsible for the defeat at Actium - and thus Antony's position becomes less ambiguous. Whilst it is certainly not the case that the earlier portrayals of Antony were not to some degree feminized, in the presence of the recuperated Cleopatra these feminized characteristics are perniciously reconfigured as both definitive and - crucially - destructive.

The corollary of this paradigm shift is that the meaning attached to any element of the iconography of Mark Antony's screen constructions must also shift to encompass his revised narrative function. However, the presence of the Augustan line is so pervasive that the iconography itself remains fairly stable, although the semantic function of each item may alter. Briefly, these are as follows (a more detailed discussion continues below):

- alcohol abuse

- lechery

- tearful despair

- consuming love

- feminized dress

- political inability

- the abandonment of Roman duty

- quasi-sociopathic behaviour

- the absence of his children from the narrative

- the infantilisation of his character

- a narrative structure that allots equal run-time to both Caesar's and Antony's affairs with Cleopatra

- Antony presented as a gift to Cleopatra

- the positioning of other male characters, often rivals to Cleopatra's affections, whose embodiment of appropriate masculinity is above reproach

The first seven items in the list are directly derived from Augustan propaganda; however, the final six are inventions of the twentieth- and twenty-first century screen narratives. To return briefly to my earlier discussion of a teleologically determined text: these narratives do not simply follow the Augustan discourse of the Roman man ruined by incontinentia and mollitia (and, not incidentally, by the caprice of a woman who will not learn her proper place) - rather, they expand upon this discourse and make it a twentieth and twenty-first century morality tale imbued with contemporaneous cultural references. Antony feminized by Roman invective, it seems, is simply not feminine enough to get the point across.

Alcohol abuse is ubiquitous to Antony's screen constructions, and reflects his character's tendency to consume alcohol to the extent that his ability to act as a leader is compromised (direct corollaries of this item are political inability and dereliction of 
duty). This is, of course, directly linked to contemporaneous Roman political invective: Marcus Tullius Cicero, a vocal opponent of Antonius and an acknowledged master of Roman oratory, immortalised their political dispute in his Philippics, a series of published speeches in which he extravagantly employs incontinentia, mollitia, and inventio to further his claims that Antonius is unfit for Roman office. Antonius is 'worn out with drunkenness and debauchery' ( $2^{\text {nd }}$ Philippic, III), and 'always drunk' ( $5^{\text {th }}$ Philippic, IX), he charges. Antony's responses to the allegations are apparently lost to antiquity, although Cicero refers to them in other Philippics. Later, during the propaganda war with Octavian, accusations of alcoholic excess proved so pervasive and damaging that Antonius felt obliged to issue a rebuttal, De Sua Ebrietate (On His Drunkenness), of which only the name and textual allusion apparently survive. It is certainly possible that there is truth in these stories; however, given their ideological positioning, and given that they are further complicated (albeit post-Cicero's death) by Antonius's association with Cleopatra and the East, which Beth Severy contends Romans 'coded...as effeminate in contrast to their own inherent masculinity in order to express contemporary geopolitical relationships,' (2003, pp.23-24) it is clear that they cannot be considered fundamentally reliable.

However, without exception, this image of Antonius the alcohol abuser (alcoholic may be implied, but is never directly stated) is unproblematically reproduced on screen. Serpent of the Nile (1953) has Antony grow steadily more dependent on alcohol as his attachment to Cleopatra deepens, reflected in his complete loss of control in the final scenes before Alexandria falls. Likewise, in Cleopatra (1963), Antony's tendency to over-consume alcohol is used first to undermine his ability as a politician, and later to actively demasculinise him. A minor scene with Rufio (who is positioned as a commentary on Antony's deficient masculinity) makes this explicit. Stunned by the news that Octavian has stripped Lepidus (the historic third member of the triumvirate, rarely featured on screen) of his command, he murmurs, 'I wish I had not drunk so much today':

\author{
Rufio \\ So do I.
}

Antony

Do I trouble you, Rufio?

Rufio

Yes you do.

(Mankiewicz 1963)

Cleopatra (1999) has Antony, already established as 'Quite the Dionysian' in an early scene with Cleopatra, descend into alcoholic despair following his defeat at Actium. Cleopatra, again afforded superior (masculine) control over her emotions, demands, 'How long are you going to stay drunk?' He breaks down and weeps, 'I fear I can lead no more...' (Roddam 1999).

Lechery, of course, shares a semantic root with alcohol abuse in Roman invective, being linked to incontinentia, and as such is another recurrent charge against Antonius. Cicero, predictably, accuses him of all manner of debauchery (including sexual passivity in an 
alleged relationship with the notorious demagogue Publius Clodius, almost the definition of mollitia). Octavian also clearly levelled similar allegations during the 30s, as revealed by a surviving fragment of Antonius' response:

What has made such a change in you? Because I lie with the queen?... What then of you - do you lie only with Drusilla? Good luck to you if when you read this letter you have not been with Tertulla or Terentilla or Rufilla or Salvia Titisenia or all of them.

(Suetonius: Augustus, LXIX)

Lechery is a problematic term, so I have taken it to refer to an inappropriate display of sexual desire, specifically where the desire is not reciprocated by its object (under which terminology I include any commercial transaction with prostitutes). For this reason, although it might certainly be argued that this constitutes inappropriate sexual expression, I have chosen to exclude Antony's rough courtship of Cleopatra in 1963 and 1999, as it is ultimately made clear that his affection is reciprocated.

The 1934 Production Code, whilst it was in force, almost certainly influenced the adoption of alcohol abuse over lechery as Antony's on-screen vice of choice, and, as such, it only gradually becomes established as a key feature of his iconography. Serpent of the Nile's Antony is undoubtedly a sensualist, and he is introduced to the audience in his first dialogue scene sharing a passionate kiss with an unidentified woman. 'Life may be short,' he tells her, 'but there is always time for pleasure' (Castle 1953). This is, however, the only lecherous interlude in the run-time, and, given his propensity for alcohol consumption, his lechery might be more properly considered as a device for establishing his profligate character than a separate trait in itself.

Similarly, the Antony of Cleopatra (1999) exhibits only one isolated example of lecherous behaviour; indeed, so incongruous are his actions that the effect is narratively startling. As Antony arrives on Cleopatra's barge for their famous meeting at Tarsus, the arrangement of the scene makes clear (as the dialogue does not) that Cleopatra's intention is to seduce Antony, and the camera treats her as sexual object, drifting across her supine body as she chews seductively on a piece of fruit. 'This is an unexpected pleasure,' he says, seating himself on the couch beside her:

Cleopatra

You never came to Egypt to visit me.

Antony

You never invited me. Three years I've waited.

Cleopatra

You were too busy fighting wars.

Antony

I'm never that busy.

Cleopatra

Shall we retire? 


\author{
Antony \\ Of course. \\ (He lies back on the couch with a salacious grin) \\ Cleopatra \\ To dinner.
}

(Roddam 1999)

Flirtatious banter notwithstanding, she is dignified and remote in her conversation, and nothing about her behaviour towards him makes plausible his assumption that when she says retire she means to bed. We can only presume that his (supposed) sexual licentiousness has fostered in him the belief that all women are sexually available to him. However, once their relationship is consummated it immediately assumes the dynamics of a monogamous couple for the remainder of the run-time, regardless of his subsequent marriage to Octavia, which is never shown.

Feminized dress includes the use of cosmetics up to and including transvestitism - which is a reading of the Shakespearean text suggested by one scholar - and is linked to Antony's association with Hercules. The legend of Hercules and Omphale was wellknown in late Republican Rome, and was used to denigrate Antony's relationship with Cleopatra and to position him as the emasculated conquest of her love. Hercules is described by Ovid as follows:

She gave him gauzy tunics in Gaetulian purple dipped; she gave him the dainty girdle, which but now had girt her waist. For his belly the girdle was too small; he undid the clasps of the tunics to thrust out his big hands. The bracelets he had broken, not made to fit those arms; his big feet split the little shoes. She herself took the heavy club, the lions skin, and the lesser weapons stored in their quiver.

(Ovid: Fasti, II.81)

This is a description that is almost exactly duplicated in Rome's Marc Antony, as he becomes upon his arrival in Cleopatra's Alexandria. Dressed in a pinkish-purple, flimsy tunic that looks more like a dress, with heavy eye make-up and golden bracelets, he is the embodiment of the emasculated Hercules in his captor-queen's clothes (2007: 9). Elsewhere, the transformation is less pronounced but rarely absent: as his sojourn in Alexandria continues, the hairstyle sported by Serpent of the Nile's Antony grows steadily longer; in 1963's Cleopatra, it is Antony, not Cleopatra, who is found bathing in asses' milk.

The gendering of despair and overwhelming grief as feminine or feminizing is again directly derived from Roman invective. Craig A Williams, in his discussion of masculinity and effeminacy in ancient Rome, examines the surviving ancient sources for evidence of contemporaneous attitudes to the reason/emotion dichotomy. His findings echo Edwards' discussion of incontinentia:

The Roman conceptualization of masculinity as being embodied in restraint and control, over others and oneself, informs two concepts basic to Roman masculinity: virtus and imperium. The first of these two words displays a significantly gendered quality. Derived from vir and thus etymologically 
meaning "manliness," virtus came to be used of a variety of moral traits considered admirable in men - concepts that might be translated as "valor" or "virtue". Effeminate men, of course, failed to live up to this standard.

(Williams 1999: 132)

Plutarch's account of Antonius's despair following his defeat at Actium, and his subsequent self-imposed isolation on his return to Alexandria, given that Roman convention would certainly have gendered such behaviour feminine and thus cast Antonius's leadership ability into question, may of course be apocryphal; nevertheless, it is referenced again and again in Antony's on-screen appearances. If his historical suicide is certainly a contributory factor in the faithful reproduction of this element of the myth, being of course elided in western mythology with despair (and, in romantic narratives, with tragic love), it is a projection of contemporary discourse onto an act that, for Roman men, carried connotations not of weakness, but of honour in defeat.

Closely linked to his alcohol abuse (and, again, ubiquitous), most representations conceive of Antony's despair as a kind of mental collapse, in which his tearful dissolution is always opposed to Cleopatra's stern self-control. His all-consuming love is connected to this, both semantically and literally, and the screen Antony generally cites this during his breakdown as the reason for his loss of selfhood and defeat. The ancient sources are clear that excessive emotion, be it love or despair, is essentially feminizing. Once again, we refer to Cicero:

There is in the soul of every man something naturally soft, low, enervated in a manner, and languid. Were there nothing besides this, men would be the greatest of monsters; but there is present to every man reason, which presides over, and gives laws to all; which, by improving itself, and making continual advances, becomes perfect virtue. It behoves a man, then, to take care that reason shall have the command over that part which is bound to practice obedience... If that part of the soul which I have called soft behaves disgracefully, if it gives itself up to lamentations and womanish tears, then let it be restrained, and committed to the care of friends and relations...

(Tusculan Disputations, II.21)

A man who allows emotion to master his reason is less of a man. Again, the manifestation of this item is largely dependent on the narrative sympathy afforded to Cleopatra. When Antony despairs, he despairs that his love for her has been his ruin, and, where Cleopatra performs the femme fatale, there is a certain justification for his position: whether or not her intention has been malicious (and it rarely is; even Cecil B DeMille's 'wickedest woman in history' (DeMille cited in Hughes-Hallett 1990: 269) displays considerable affection towards Antony and is only reluctantly persuaded to move against him when political expedience obliges), he has been explicitly positioned as a means to an end, and his downfall is a corollary of her over-reaching ambition. However, as she is recuperated, it is rather he that causes her downfall, and, implicitly, this is usually because his unrestrained love for her has feminized him to the point that he is unable to act rationally, let alone decisively or politically. Thus, 1963's Cleopatra, having trotted out the standard Augustan version of the events at Actium - to whit: Antony, spotting Cleopatra fleeing the Battle of Actium, abandons their fleet in the middle of battle to follow her - has him morosely acknowledge his dereliction of 
selfhood. 'They told me you were dead!' cries Cleopatra. 'They were quite right,' replies Antony. 'I am dead' (Mankiewicz 1963).

He rails against the subduction of his (masculine) will to his (feminine) love for her. At Actium, he says, all he could think was 'that my love was going and that I must be with her! That my love, my master called! And I followed her. And I followed'

(Mankiewicz 1963).

If Antony's acquiescence to the dictates of emotion over masculine reason did not adhere closely enough to Cicero's idea of disgraceful behaviour, he compounds his error in 1999's Cleopatra by succumbing to 'womanish tears' (Cic. Tusc. II.21). Berated by Cleopatra at his beach-side retreat for sliding into drunken despair, he is slumped on the ground while she assumes the position of power over him. It takes very little to reduce him to tears: furious at his dissolution, she demands, 'Could I have misjudged you?' He replies, 'It may be your nature to see victory in defeat, but it is not mine, I fear. I fear...' he adds, and begins to weep copiously, 'I fear I can lead no more' (Roddam 1999). There is nothing subtle about this: Antony has been explicitly feminized (at one point, Cleopatra knocks his sword from his grasp, adding the final touch to his symbolic emasculation), and, feminized, he is no longer fit for leadership.

Even the hyper-masculine Antony of 2007's Rome: Season 2 is not immune to this most faithful reproduction of Augustan myth: presiding over an Alexandrian orgy the day before his suicide, Antony is uncoordinated, drunk, and devoid of hope. Reporting on the pair in Rome, Octavian's source calls him 'drunk, or drugged,' whilst Cleopatra is 'sober... alert' (BBC/HBO 2007: 10). Determined to the end to avert catastrophe, she pleads with him to help her think their way out of their predicament: 'You're so good at that,' she says. He turns to her, his face a mask of sorrow: 'I'm a soldier,' he tells her, 'I'm not a fucking magician' (BBC/HBO 2007: 10).

A direct extension of his feminized behaviour is the implication that, in allying himself with Cleopatra, Antony is abandoning Rome. This is semantically linked with two separate but interlinking discourses: the intrinsically Roman (although it is reliably projected into modern narratives) idea that the east was irredeemably effeminate, and thus that a display of philhellenism was consonant with blatant mollitia (Edwards 1993: 93), and the modern predilection in western narratives towards allying Rome with Us and NotRome with Other (the exception being, of course, when the narrative in question deals with ancient British resistance to Roman occupation, at which time Rome becomes Other). These two ideas are, of course, two sides of the same coin: Rome as masculine versus East as feminine is just another way of expressing Us and Them. However, it does re-root the discourse firmly within the sphere of gender anxiety. As Edwards notes, Roman political invective regarding Antony's relationship with Cleopatra was exploited to imply that, not only had he made himself subject to an eastern queen, but he had outdone her in extravagance (Edwards 1993: 25). If woman, eastern, and extravagant are elided in Roman discourse as Other, then Antony has not only Other-ed himself, but is now more Other than the Other. Clearly, then, political ineptitude is the inevitable result: even to modern audiences unaccustomed to sifting the nuances of meaning from Roman accusations of debauchery, extravagance, and gluttony, it is fairly clear that a man regularly subjected to such excesses would, at the very least, find himself mentally and physically unfit for the intricacies of statesmanship. For obvious reasons, it is a common charge levelled at Antony, and has tended to be unproblematically accepted as fact, 
irregardless of the fact that, for a man apparently deranged by sensual indulgence and held captive by love, he enjoyed a relatively long and successful career as one of the most powerful men in Rome.

The reconfiguration of the majority of these narratives as a tale of doomed or misguided romance has tended to edge the political minutiae out of the plot; thus Serpent of the Nile (1953) nods in the general direction of the collapse of the Roman Republic by opening on Caesar's assassination, but grounds itself instead in the tale of Cleopatra's internecine bid for power. Denied any political sphere in which to shine or otherwise, Antony is perhaps best viewed as an appendage to the main story: when he moves in tangent with the political backdrop of the time, it is simply a device by which to move forward the story of how Cleopatra will use him to her own ends. Cleopatra (1963) is less dismissive: here, Antony is actively damaging to their cause, abusing his generals for disagreeing with his foolhardy plans at Actium, and publicly bristling at Cleopatra's superior ability:

Antony

My men will do as they are told by me! They have not yet become... they are still Roman. However - as I do as I am told....

(He drinks a large draught of wine)

\section{Cleopatra}

The final decision will of course be Lord Antony's, and I am sure that - in time - he will make it. That is all.

(The officers leave)

It would be wiser, I think, not to disagree in the presence of our officers.

Antony

Your officers. And what final decision have you decided I am to make?

(Mankiewicz 1963)

Indeed, the script explicitly denies him political ability. In reflective mood, Antony muses: 'Show me a city and I'll tell you how to take it. Let me face an army and I'll smell out its weak points and hit them hard where they are. Make me to sit down, talk in whispers of this and that, with an emphasis here and a shrug there and I'm soon confounded and defeated. Meaning to do the best, I suppose... I suppose I could not have done worse' (Mankiewicz 1963).

By 1999, Antony and Cleopatra are actively seeking to provoke war with Octavian. In fairness, this is in large part due to Cleopatra's ultimatum that he either break with Octavian or never see her again, but, whilst she may be politically incompetent, he seems to be incapable of even forming a political opinion, much less a line of action, on his own. Throughout the script, he is almost entirely lacking in agency. Cleopatra's poor decisions are recuperated by a narrative thread that presents her as the nurturing mother, 
desperate to protect her son by Caesar; Antony is simply out of his depth. The triumvirate's division of the Roman empire (once again, lacking Lepidus) is motivated by Antony's powerful desire to return to Cleopatra, not by any appreciation of its potential as a robust power-base, which allows Octavian to capitalise on Antony's carelessness. Within a couple of scenes, it's all academic anyway: Antony has publicly renounced his 'false Roman marriage' (Roddam 1999) to Octavia, sister of Octavian, which was conducted (with a basis in historical fact) in order to seal their allegiance. He ignores the increasingly desperate advice of his generals to avoid a civil war (which terminology the historical Octavian went to great lengths to avoid; in declaring war on Cleopatra alone, he sought to ensure that no such accusation could be levelled at him), and later reprises the 1963 scene at Actium, where, against everyone's advice, Antony once again makes the catastrophic decision to fight by sea. At no point is it hinted, in line with JM Carter's 1970 re-interpretation of the battle (now widely accepted as a more realistic interpretation of the known facts), that Actium in fact represented a strategic retreat in the face of the gross depletion of forces by disease and hunger - which would mean that the manoeuvre was actually a comparative success (Carter 1970: 215-228).

By the time Antony appears on the twenty-first century screen, any political power he retains is predicated on violence. Unlike his earlier incarnations, he is no longer divorced from Roman politics, perhaps because, thus far, the twenty-first century has yet to retell Cleopatra's story - where Antony appears, he is a player in a larger Roman story, to which Cleopatra is the appendage - yet, whilst he may move in political circles and enact the great political events of the end of the Republic, he displays no inherent political comprehension and relies instead on brute force or the threat thereof. Therefore, when Octavian returns to Rome after Caesar's assassination in Imperium: Augustus (2002), he perceives the threat presented by Antony, but it is not the political threat of a young, unproven ingénue who seeks to contest the power of a wildly popular politician of many years' standing, it is the threat of Antony's unpredictable recourse to violence. 'Killing served him,' intones the older Augustus in voiceover. 'He embraced it' (Young 2002). A similar volatility informs the Antony of Rome (2005-7): danger simmers beneath the surface and erupts without warning - witness the serpentine smile he bestows upon Quintus before spinning around and slitting his throat (2007: 1), or his brutal murder of a Senator who is tasked with reading out an insulting letter to Antony from Cicero (2007: 3 ). His political acumen is based on a sort of animal cunning, and it requires the superior intellect of a Caesar or a Cleopatra to refine it and make it useable. Antony would have had first Pullo (for his failure to return the stolen treasury gold), then Vorenus (for his failure to apprehend the fleeing Pompey) severely punished, but it is Caesar, with his eye on the bigger picture - the political picture - who employs tactical restraint. 'I don't know how you tolerate that man,' complains the ascetic Brutus, to which Caesar replies, 'He likes to fight' (BBC/HBO 2005: 1).

Excessive violence, indeed, becomes Antony's signature vice in the twenty-first century an aspect of his characterisation that, hitherto, had been noticeably absent. DeMille in 1934 might have had his Antony declare that he was going to Tarsus 'to send Cleopatra to Rome in chains' (DeMille 1934), but he is easily diverted on his arrival - indeed, Marcus Antonius the soldier's soldier and veteran of battles from Gaul to Philippi is conspicuously absent on screen. When he is shown in battle, his presence as soldier is undermined: he is drunk (1963), his battle skills are inferior to Cleopatra's (1999), or he simply loses every battle he enters (all). Violence and the feminized Antony do not make comfortable bedfellows. 
His transformation from Cleopatra's pawn to id-driven monster, then, has been as startlingly rapid as it is inherently problematic. In 1999, he weeps in Cleopatra's arms; by 2002, he is a sadist worthy of the comment: 'That was Mark Antony. You're lucky you still have your head' (Young 2002). It would seem that Antony's hyper-masculinity, typified by both violence, and (in Rome) unrestrained lust, references the interrogation of hegemonic masculinity that has taken place over the past decade or so. The commentary that Antony provided on masculinity in the 20th century has been a masculinity that is increasingly recognised as being as much a construction of patriarchally-conceived gender roles as was the femininity interrogated by second wave feminism: damaging, restrictive, and essentialist. As scholars from a variety of disciplines have sought to reposition acceptable masculinity, various gendered notions have been challenged - in particular, the positioning of emotional expressivity as a 'feminine' trait. It is notable, then, that Rome's Antony does not sink into gendered despair and does not surrender his reason to love: the romanticizing elements are absent from this re-telling of the myth and, though the word 'love' is mentioned, it is rendered uncertain and is given no support by the narrative or the diegetic material. When Antony breaks down, it is as a response to Cleopatra's death - perhaps the only appropriate emotional display available from the character throughout the two seasons. Instead, the deficiency of this Antony's masculinity is conceived of in opposition to a problematised hegemonic masculinity: pathologically sexual, brutally aggressive, generally devoid of human emotion. The emotional breakdowns belong to his counterpart Vorenus, who is properly distraught at the loss of his family and his part in Caesar's murder, and who is conceived of as the honourable, emotionally appropriate family man.

This paradigm shift in the positioning of deficient masculinity has an interesting corollary: the gradual emergence of Antony's children into the narrative. Antony had at least seven children - three by Cleopatra, two by Octavia, and another two by Fulvia, his fiercely intelligent and politically active second (or possibly third [Goltz-Huzar 1978:25]) wife whose absence from these narratives is in itself worthy of note - yet before Augustus (2002), they were conspicuous by their screen absence. Augustus is confused in its rendering, appearing to suggest that Iullus Antonius, the only child of Antony depicted on screen, is the son of Antony and Cleopatra (he was in fact his second son by Fulvia); however, after this inauspicious start, Rome finds him three times a father, with two of his children by Cleopatra shown and reference made to one daughter by Octavia (although the narrative suggests that it is equally likely that paternity belongs to Marcus Agrippa).

The absence of Antony's children from the earlier narratives poses a clear challenge to his masculinity, by challenging his virility (a word that shares an etymological root with virtue, and which is derived from the Latin word vir, meaning manliness) - not least in those narratives that oppose his apparent childlessness with the regular (although not ubiquitous) appearance of Caesarion, Cleopatra's son by Caesar. It would also seem to suggest an answer as to why Antony's lechery, where it exists, is positioned negatively (for surely virility is only the flip side of sexual promiscuity): virility implies healthy reproduction, whilst lechery implies a pathological behaviour. Sexual excess that does not lead to reproduction, it would seem, is wasted energy, and a man that indulges in sexual behaviour to excess and does not father a single child, is emasculated in principle.

Therefore when lechery becomes in and of itself a pathological behaviour, a signifier of a hyper-masculinity that has been interrogated and found wanting, it becomes its own 
critique. Reproductive or not, there is nothing healthy about a man who holds up a column of soldiers on the march so that he can rape a shepherdess in a nearby copse (2005: 2) or who baldly announces on the morning of Caesar's funeral, 'I am not rising from this bed until I've fucked someone' (BBC/HBO 2007: 1). Fatherhood is held in higher esteem than the ability to father a child, and it is notable that Vorenus, whose violence is controlled and purposeful, whose appetites are (for the most part) ascetic, is driven to defend not only his own children, but also the illegitimate child of his dead wife, and also the child Caesarion, whose defence costs Vorenus his life.

The eradication of Antony's children from the narrative is also in part dictated by the expediency dictated by the standard two-act structure that most of these texts adopt (the exceptions being Caesar and Cleopatra, 1946, which does not feature Antony, and Serpent of the Nile, 1953, which does not feature Caesar) wherein equal (or greater) runtime is allotted to the Caesar/Cleopatra affair, which historically lasted four years, and the Antony/Cleopatra affair, which historically lasted eleven years. No great mathematical skill is required to determine that an equal division of narrative space to two grossly unequal periods of time will necessarily be obliged to privilege Caesar's position and prejudice Antony's. Even Rome, which does not foreground either affair and focuses instead on the major Roman players, can be roughly divided into Caesar (Season 1) and Antony (Season 2), although admittedly this employs a different logic in the subdivision. In fact, Season 2 of Rome, which covers the years 44BCE to 30BCE, expands the years $44-41$ BCE over a leisurely eight episodes, which leaves Antony and Cleopatra's eleven year affair only the final two episodes to play out. Clearly the intricacies of the political situation must be lost to narrative expedience, and the plotline, which up to this point had had twenty hours of run-time to explore the nuances of the highly complex politics surrounding the end of the Republic, defaults to the standard tale of corruption by love.

The final two items in Antony's iconography - his infantilisation and his commodification - are only rarely displayed, but are significant in their candour. There is nothing ambiguous about either: when Caesar, at the end of Caesar and Cleopatra (1946) offers to send Antony to Alexandria, it is clearly by way of a reward for her good behaviour. She has learned to do as Caesar (here a father-figure and specifically not a lover) tells her, and, in return, Caesar gifts her with Antony, whose looks and physique she admired as a child. In absentia, and without so much as showing his face on screen, he has become the object of a sort of meta-gaze; lacking any kind of agency, he will go where he is bidden to be a present for an excitable girl. Likewise, the Antony of 1999's Cleopatra goes one step further and objectifies himself. Having previously refused Cleopatra's demands that he break his pact with Octavian if he wants to resume their affair in Egypt, no sooner has he effected a political marriage to Octavia than he has changed his mind. Arriving in Alexandria to crowds of adoring citizens showering him with flowers (in direct contrast to Caesar, who marched through the streets at the head of a businesslike Roman army), he presents himself to Cleopatra, waiting on a dais outside the palace. 'Why have you come?' demands Cleopatra. 'Are you here to collect taxes, steal grain for Egypt's debt? Inspect your conquest?' Note that these are all Roman or military preoccupations, and all were Caesar's stated intentions on his arrival at Alexandria. But Antony demurs: 'I'm here to taste Egypt's pleasures,' he says. 'And to bear you a fine gift...myself' (Roddam 1999).

It is also in 1999 that Antony's infantilisation is most explicit. Arguably, he is rendered childlike by many of the same means that are used to interrogate his masculinity: 
Cleopatra's attempts to comfort him in his despair recall a mother with an inconsolable child; his impulsive and unpredictable behaviour in Augustus and Rome evoke a toddler subject to the demands of the id without yet having developed a constraining superego. 1999's Cleopatra is unique, however, in unequivocally labelling him as such. Observing Antony play-fighting with Caesarion, Cleopatra is pleased with the bond that has developed between them:

\section{Cleopatra}

He's wonderful with the child

\section{Olympos}

I shouldn't wonder - he's a child himself. (Roddam 1999)

Olympos, Cleopatra's friend and physician, is positioned as the voice of reason throughout the narrative, speaking against several of Cleopatra's desires (to conceive a child by Caesar, later to spare Antony's life when Octavian offers to exchange her kingdom for Antony's head) and in some ways he could be considered the external manifestation of Cleopatra's own superego, constantly struggling to mitigate the damage caused by her id-driven actions. Indeed, Cleopatra herself, for all her obvious affection and skill as a mother, for all the lip-service paid to a political intelligence that is sorely lacking in evidence throughout the narrative, is herself childlike in this incarnation: her temper tantrums, her bickering with her sister Arsinoë over who loved their father more, and her stubborn determination to have her own way (or her sulks when she can't) suggest a spoiled schoolgirl. It is Olympos's acerbic commentary on Cleopatra's illconsidered choices that recuperate her actions somewhat: at least she has an adult in charge. Antony, for his part, is a man-child reliant on a supremely immature mentor, which only reinforces Olympos's position as commentator on Antony's masculinity: Antony, as a 'child himself', is ill-suited to the role of Cleopatra's protector, although he and she have colluded in the illusion that this is his function in her life. Olympos, on the other hand, mature, sensible, and man-like, truly knows how to protect Cleopatra - but she doesn't want to listen to him. In the face of such wilful stupidity, how could disaster possibly be averted?

If it is significant that the twenty-first century has yet to reimagine the life of Cleopatra on screen, it is important to bear in mind that Antony himself has never been elevated from his role of side-player in other people's tragedies. Rome has come closest, affording him a key position in an ensemble without a clear lead. Yet the inescapable fact is that the title credit has been almost exclusively Cleopatra's throughout the twentieth century (with the exception of those screen adaptations of the Shakespearean tragedy and the play by George Bernard Shaw), and, in the twenty-first, when the focus has shifted to the Romans, Caesars Augustus and Julius have led the vanguard and hoarded the credit. Antony, the also-ran, has yet to be the star of any re-working of the key events of his life.

In examining the iconography of Mark Antony, I have attempted to demonstrate that, despite the widely divergent narrative structures of the texts in question, they all betray a common imperative: the arbitration of conflicting notions of acceptable gender positioning. Certainly, we could look at the unproblematic reproduction of Roman gendered discourses as projections into the 21 st century, divorced from their original meaning, but that, in itself is telling: the historical narrative is re-written and reconceived 
according to the meanings attached to both Antony and Cleopatra in any given historical moment, yet the iconography has remained largely unchanged throughout a complicated re-negotiation of gender roles throughout the past hundred years. This would suggest that Antony's iconography speaks, at some fundamental level, to hegemonic constructions of masculinity where it is reproduced; the significant re-working of Antony's deficient performance of masculinity in twenty-first century texts reflecting wider debates on the constitution of acceptable masculinity as academic interrogation begins to position traditional ideals of masculinity as undesirable. Audience figures would appear to confirm the relationship between the Antony-icon and dominant contemporaneous models of masculinity: even the 1963 film, whilst it did not recoup its budget, underperformed not at the box office, where it was one of the highest grossing movies of the $1960 \mathrm{~s}$, but in reigning in the production expenses (the movie cost $\$ 40$ million to produce - in adjusted dollars, that figure would be closer to $\$ 440$ million today). Two thousand years after their deaths left them wide open to conflicting semantic attachments, Antony and Cleopatra, paragons of gender anxiety, remain big business on screen.

\section{References}

Carter, J.M. (1970). The Battle of Actium: The Rise and Triumph of Augustus Caesar. London: Hamish Hamilton

Cicero, M. T. (1852). 'Second Philippic' and 'Fifth Philippic' in The Orations of Marcus Tullius Cicero. Translated from Latin by CD Yonge. London: Henry G Bohn

Cicero, M. T. (1853). 'Tusculan Disputations' in The Academic Questions: Treatise De Finibus, and Tusculan Disputations. Translated from Latin by CD Yonge London: Henry G Bohn

Cohen, S. (1997). Masked Men: Masculinity and the Movies in the Fifties. Bloomington and Indianapolis: Indiana University Press

Edwards, C. (1993). The Politics of Immorality in Ancient Rome. Cambridge: Cambridge University Press

Gibson, P.C. (2004). 'Queer Looks, Male Gazes, Taut Torsos and Designer Labels: Contemporary Cinema, Consumption and Masculinity', in Phil P., Ann D., and Bruce B. eds. The Trouble With Men. London: Wallflower Pres

Goltz-Huzar, E. (1978). Mark Antony: A Biography. Minneapolis: University of Minnesota Press

Hughes-Hallett, L. (1990). Cleopatra: Histories, Dreams and Distortions. London: Bloomsbury

Lehman, P. (2001). Masculinity: Bodies, Movies, Culture. New York and London: Routledge

Ovid: Fasti. Translated from Latin by James George Frazer (1929) Basingstoke: Macmillan 
Royster, F.T. (2003) Becoming Cleopatra: The Shifting Image of an Icon. New York: Palgrave Macmillan

Severy, B. (2003) Augustus and the Family at the Birth of the Roman Empire. New York and London: Routledge

Shamir, M. and Jennifer T. (eds) (2001) Boys Don't Cry: Rethinking Narratives of Masculinity and Emotion in the US. New York: Columbia University Press

Williams, C. A (1999) Roman Homosexuality: Ideologies of Masculinity in Classical Antiquity Oxford: Oxford University Press

\section{Filmography}

Cleopatra (1934). Directed by DeMille, C. USA: Paramount Pictures Inc. [DVD]

Serpent of the Nile (1953). Directed by Castle, W. USA: Columbia Pictures [video: VHS]

Cleopatra (1963). Directed by Mankiewicz, J. USA: Twentieth Century Fox / MCL Films SA / Walwa Films SA [DVD]

Cleopatra (1999). Directed by Roddam, F. USA: Babelsberg International Film Produktion / Hallmark Entertainment [DVD]

Imperium: Augustu. (2002). Directed by Young, R. Italy: EOS Entertainment / Lux Vide / Radiotelevisione Italia / Telecinco / Zweites Deutches Fernsehen [DVD]

Rome: Season 1 (2005). USA: HD Vision Studios / BBC / HBO [DVD]

Rome: Season 2 (2007). USA: HD Vision Studios / BBC / HBO [DVD] 